\title{
PENERAPAN METODE BIOKLIMATIK DALAM DESAIN RUSUNAMI YANG INTERAKTIF,SEHAT DAN AKTIF
}

\author{
Clairine Aloysia Benedicta ${ }^{1)}$, Sidhi Wiguna Teh ${ }^{2)}$ \\ 1)Program Studi S1 Arsitektur, Fakultas Teknik, Universitas Tarumanagara,claireab@yahoo.co.id \\ 2) Program Studi S1 Arsitektur, Fakultas Teknik, Universitas Tarumanagara,sidhi@ft.untar.ac.id
}

\begin{abstract}
Abstrak
Jakarta merupakan salah satu wilayah yang pesat dalam hal kependudukan. Kota Jakarta sebagai Ibu Kota Negara Republik Indonesia memiliki perkembangan dan kemajuan yang sangat pesat di berbagai bidang dan sektor seperti sosial, ekonomi, budaya dan politik. Karena daya tarik yang ditimbulkan oleh Jakarta, hal tersebut memicu urbanisasi yang menyebabkan jumlah dan kepadatan penduduk Jakarta terus meningkat setiap tahunnya. Dengan adanya peningkatan jumlah penduduk maka kebutuhan akan hunian juga meningkat. Rumah susun menjadi salah satu solusi untuk menjawab permasalahan pertumbuhan populasi itu. Rumah Susun dianggap menjadi jawaban bagi kebutuhan pemukiman di wilayah perkotaan, khususnya bagi masyarakat menengah ke bawah. Studi ini menggunakan metode "Arsitektur Bioklimatik" sebagai pendekatan desain perancangan yang mengacu pada desain bangunan dan ruang (interior - eksterior - luar ruangan) berdasarkan iklim lokal, yang bertujuan untuk memberikan kenyamanan termal dan visual, memanfaatkan energi matahari dan sumber lingkungan lainnya. Elemen dasar dari desain Arsitektur Bioklimatik adalah sistem Passive Solar Systems yang dimasukkan ke dalam bangunan dan memanfaatkan sumber lingkungan (misalnya matahari, udara, angin, vegetasi, air, tanah, langit) untuk pemanas, pendingin dan penerangan bangunan. Penerapan metode bioklimatik pada rusunami bertujuan untuk menjadi solusi untuk permasalahan ekologi dan efektivitas penggunaan material dengan tujuan meningkatkan kualitas hidup warga dan menjadikan lingkungan yang interaktif, sehat dan aktif dengan mengoptimalkan unsur alam dan penerapan program ruang yang tepat diharapkan dapat bermanfaat untuk digunakan.
\end{abstract}

Kata kunci: Arsitektur Bioklimatik; Rumah Susun; Kesehatan; Sosial

\begin{abstract}
Jakarta is one of the fastest growing areas in terms of population. The city of Jakarta asthe capital city of the Republic of Indonesia has very rapid development and progress in various fields and sectors such as social, economic, cultural and political. Due to the attractiveness of Jakarta, it triggers urbanization which causes the number and density of Jakarta's population to continue to increase every year. With the increase in population, the need for housing also increases. Flats are one solution to the problem of population growth. Flats are considered to be the answer to the housing needs in urban areas, especially for the lower middle class. This study uses the "Bioclimatic Architecture" methodas a design approach that refers to the design of buildings and spaces (interior - exterior-outdoor) based on the local climate, which aims to provide thermal and visual comfort, utilizing solar energy and other environmental sources. The basic element of the Bioclimatic Architectural design is Passive Solar Systems which are incorporated into the building and utilize environmental sources (eg sun, air, wind, vegetation, water, soil, sky) for heating, cooling and lighting of the building. The application of the bioclimatic method on rusunami aims to be a solution to ecological problems and the effectiveness of the useof materials with the aim of improving the quality of life of residents and making an interactive, healthy and active environment by optimizing natural elements and theapplication of appropriate spatial programs is expected to be useful for use.
\end{abstract}

Keywords: Bioclimatic Architecture; Flats; Social; Wellness 


\section{PENDAHULUAN}

\section{Latar Belakang}

Provinsi DKI Jakarta selain sebagai ibu kota Republik Indonesia juga dianggap sebagai kota pusat ekonomi bisnis di Indonesia. Hal ini menyebabkan banyak penduduk dari luar DKI Jakarta ingin berpindah pemukiman ke DKI Jakarta. Pada Maret 2020, Dinas Kependudukan dan Pencatatan Sipil mencatat sebanyak 7.421 jiwa penduduk yang datang bermigrasi ke kota Jakarta ini. Peringkat ketiga teratas dengan jumlah penduduk terbanyak yang masuk ke wilayah DKI Jakarta adalah Jakarta Selatan dengan penduduk sebanyak 1.281 jiwa pertahunnya.

Ketersediaan sarana dan prasarana yang lengkap di kawasan Jakarta Selatan merupakan salah satu alasan menjadi daya tarik bagi masyarakat dari dalam kota itu sendiri maupun dari luar wilayah kota, sehingga menyebabkan pula tingginya arus urbanisasi. Urbanisasi telah menyebabkan ledakan jumlah penduduk kota yang sangat pesat, dampak dari tingginya arus urbanisasi kota adalah dalam hal permukiman kota. Para urbanis membutuhkan tempat hunian yang berada di sekitar kawasan komersial kota karena dekat dengan perdagangan untuk membuka usaha dengan memanfaatkan keramaian dan padatnya pengunjung yang berdatangan ke pusat-pusat perbelanjaan di kota, alasan lain bagi masyarakat tertarik untuk bertempat tinggal di sekitar kawasan pusat kota karena lebih mudah menjangkau tempat kerja.

Untuk memenuhi kebutuhan rakyat akan perumahan dan pemukiman yang dapat dijangkau oleh masyarakat yang berpenghasilan rendah dan untuk memenuhi era pola hidup modern, pemerintah Indonesia selalu dihadapkan pada permasalahan keterbatasan lahan yang tersedia untuk pembangunan hunian di daerah perkotaan yang berpenduduk padat. Efektifitas penggunaan tanah sangat diperlukan sehingga bermanfaat bagi masyarakat banyak. Apalagi jika di hubungkan dengan hak asasi, maka tempat tinggal merupakan hak bagi setiap warga Negara, Pada pasal $28 \mathrm{H}$ ayat (1) UUD 1945 yang berbunyi: "Setiap orang berhak hidup sejahtera lahir dan batin, bertempat tinggal, dan mendapatkan lingkungan hidup yang baik dan sehat serta berhak memperoleh layanan kesehatan."

Pengertian rumah susun menurut UU No. 20Tahun 2011 tentang Rumah Susun (UU Rusun) adalah bangunan gedung bertingkat yang dibangun dalam suatu lingkungan yang terbagi dalam bagian-bagian yang distrukturkan secara fungsional, baik dalam arah horizontal maupun vertikal dan merupakan satuan-satuan yang masing-masing dapat dimiliki dan digunakan secara terpisah, terutama untuk tempat hunian yang dilengkapi dengan bagian bersama, benda bersama, dan tanah bersama.

\section{Rumusan Permasalahan}

a. Bagaimana rumah susun bermanfaat untuk menanggapi keterbatasan lahan di JakartaSelatan untuk masyarakat berpenghasilan rendah?

b. Bagaimana metode arsitektur bioklimatik mempengaruhi lingkungan di sekitarnya?

c. Bagaimana desain bangunan mempengaruhi keamanan, kenyamanan dan kesehatanpenghuni di dalam nya?

\section{Tujuan}

a. Menciptakan sebuah lingkungan masyarakat yang memiliki kualitas hidup (fisik, psikologis, sosial, dan lingkungan).

b. Menciptakan sebuah lingkungan yang aman, nyaman dan sehat.

c. Menciptakan tempat tinggal yang maju dan berkelanjutan. 


\title{
2. KAJIAN LITERATUR
}

\section{Pertumbuhan Populasi}

Dilansir dari situs resmi United Nation, pada 2016 mencapai 7,4 miliar orang dan jumlah penduduk dunia 2020 mencapai 7,7 miliar orang. Diperkirakan pada 2030 akan tumbuh mencapai 8,5 miliar penduduk dan pada 2050 mencapai 9,7 miliar penduduk. Untuk saat ini Indonesia masuk kedalam empat besar populasi terbanyak di dunia pada 14 Desember 2020. India mengikuti China sebagai negara dengan populasi terbesar di dunia dengan jumlah penduduk 1,382 miliar. Kemudian diikuti Amerika Serikat sebesar 331,3 juta, Indonesia sebanyak 273,9 juta, dan Pakistan sejumlah 221,5 juta orang.

Badan Pusat Statistik (BPS) mencatat mayoritas dari penduduk Indonesia berpusat di Pulau Jawa. Bahkan tercatat 56,1 persen dari jumlah penduduk sebanyak 151,6 juta jiwa dalam Sensus Penduduk (SP) 2020 yang terkonsentrasi di Pulau Jawa. Pulau ini secara administratif terbagi menjadi enam provinsi, yaitu Jawa Barat, Jawa Tengah, Jawa Timur, dan Banten, serta dua wilayah khusus, yaitu DKI Jakarta dan DI Yogyakarta. Berdasarkan provinsi, jumlah penduduk tertinggi berada di Jawa Barat yaitu 48,27 juta jiwa, Jawa Timur 40,67 juta jiwa, dan Jawa Tengah 36,52 juta jiwa.

Daerah Khusus Ibukota Jakarta (DKI Jakarta) adalah ibu kota negara dan kota terbesardi Indonesia. Jakarta merupakan satu-satunya kota di Indonesia yang memiliki status setingkat provinsi. Berdasarkan data terbaru dari Dinas Kependudukan dan Pencatatan Sipil, jumlah penduduk DKI Jakarta tahun 2019 mencapai 11.063.324 jiwa, jumlah ini sudah termasuk WNA sebanyak 4.380 jiwa. Dari grafik di bawah ini, kita bisa lihat kalau Jakarta Selatan berada padaperingkat ke-4 kependudukan terpadat di DKI Jakarta.

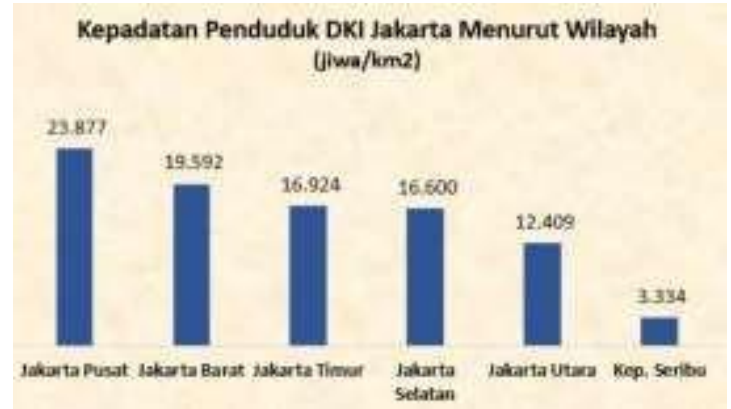

Gambar 1. Portal Statistik Sektoral Provinsi DKI Jakarta

Sumber: Pemerintahan Kota Administrasi Jakarta Selatan, 2019

\begin{abstract}
Urbanisasi
Urbanisasi merupakan proses yang terjadi akibat laju pertumbuhan penduduk yang tinggi, perpindahan penduduk dari daerah pedesaan menuju perkotaan terutama yang dapat menyebabkan perluasan fisik wilayah kota. Indonesia merupakan salah satu negara yang mengalami kenaikan penduduk yang sangat pesat, hal tersebut berdampak pada meningkatnya mobilitas penduduk. Selama kurun waktu 50 tahun terakhir (1968-2018), perkembangan urbanisasi cukup signifikan. Mobilitas penduduk desa menuju perkotaan dipicu karena kota memiliki daya tarik seperti tersedianya berbagai fasilitas seperti pendidikan, lapangan pekerjaan, hiburan dan berbagai fasilitas lainnya.

Faktor pendorong penduduk desa melakukan urbanisasi ke kota karena minimnya lapangan pekerjaan di daerah asal. Kemiskinan di desa menjadi faktor pendorong penduduk desa untuk bermigrasi karena kelahiran semakin meningkat yang menyebabkan tidak terpenuhinya kebutuhan. Kalau dilihat dari perspektif ekonomi, proses urbanisasi mampu meningkatkan produktifitas,
\end{abstract}


terpenuhinya kebutuhan jumlah tenaga kerja di perkotaan, bertambah banyaknya tenaga kerja yang berpotensi dan berkualitas. Meskipun, di sisi lain urbanisasi dapat menjadi beban fisikal tambahan terkait perbaikan infrastrukur.

\section{Rumah Susun}

Salah alasan utama pembangunan rumah susun adalah memecahkan masalah kebutuhan hunian di lokasi padat penduduk, terutama pada wilayah perkotaan. Adanya rusun dapat mengurangikawasan kumuh di perkotaan, membuat tampilan kota menjadi rapih dan tidak menutup kemungkinan bahwa bertambahnya ruang terbuka hijau. Tujuan dibangunnya rusun pun tercantum dalam Pasal 2 dan 3 UURS, No 20 Tahun 2011. Berikut isi dari pasal tersebut:

\section{Pasal 2}

Penyelenggaraan rumah susun berasaskan pada:

a. kesejahteraan;

b. keadilan dan pemerataan;

c. kenasionalan;

d. keterjangkauan dan kemudahan;

e. keefisienan dan kemanfaatan;

f. kemandirian dan kebersamaan;

g. kemitraan;

h. keserasian dan keseimbangan;

i. keterpaduan;

j. kesehatan;

k. kelestarian dan berkelanjutan;

I. keselamatan, kenyamanan, dan kemudahan; dan

m. keamanan, ketertiban, dan keteraturan.

\section{Pasal 3}

Pembangunan rumah susun bertujuan untuk:

a. menjamin terwujudnya rumah susun yang layak huni dan terjangkau dalam lingkungan yang sehat, aman, harmonis, dan berkelanjutan serta menciptakan permukiman yang terpadu guna membangun ketahanan ekonomi, sosial, dan budaya;

b. meningkatkan efisiensi dan efektivitas pemanfaatan ruang dan tanah, serta menyediakan ruang terbuka hijau di kawasan perkotaan dalam menciptakan kawasan permukiman yang lengkap serta serasi dan seimbang dengan memperhatikan prinsip pembangunan berkelanjutan dan berwawasan lingkungan;

c. mengurangi luasan dan mencegah timbulnya perumahan dan permukiman kumuh;

d. mengarahkan pengembangan kawasan perkotaan yang serasi, seimbang, efisien, dan produktif;

e. memenuhi kebutuhan sosial dan ekonomi yang menunjang kehidupan penghuni dan masyarakat dengan tetap mengutamakan tujuan pemenuhan kebutuhan perumahan dan permukiman yang layak, terutama bagi MBR;

f. memberdayakan para pemangku kepentingan di bidang pembangunan rumah susun;

g. menjamin terpenuhinya kebutuhan rumah susun yang layak dan terjangkau, terutama bagi MBR dalam lingkungan yang sehat, aman, harmonis, dan berkelanjutan dalam suatu sistem tata kelola perumahan dan permukiman yang terpadu; dan

h. memberikan kepastian hukum dalam penyediaan, kepenghunian, pengelolaan, dan kepemilikan rumah susun. 


\section{Pengaruh Iklim Terhadap Arsitektur}

Tujuan utama dari arsitektur adalah harus mampu menciptakan lingkungan hidup yang lebih baik dan sehat dengan cara menyesuaikan kondisi iklim di Kawasan tersebut. Dalam proses perancangan arsitektur pengaruh iklim ditujukan pada aspek kenyamanan manusia pada suatu bangunan dimana aktifitasnya terlaksana. Menurut Richard Neutra dalam buku "Survival Through Design", Oxford University 1955, Aspek-aspek tersebut adalah Radiasi matahari, Pergerakan udara, Kelembaban udara, Curah hujan, Suhu udara rata-rata

\section{Pengaruh Iklim Terhadap Manusia}

Manusia sebagai pemakai bangunan membutuhkan lingkungan yang sesuai baginya untuk melakukan aktifitasnya. Dalam hal ini interaksi bangunan dan iklim di sekitarnya merupakan hal yang penting hingga terbentuknya lingkungan yang dimaksud. Pengaruh iklim terhadap manusia dapat ditinjau dalam kaitan sebagai berikut:

\section{a. Iklim dan Ekologi}

Tampilan secara sadar dihasilkan oleh acuan yang timbul. Keadaan ini dapat dilihat pada sosial budayanya seperti dalam cara berpakaian dan perancangan membuat bangunan tradisional di masingmasing daerah. Dalam hal ini bangunan merupakan unsur utama yang menjadi perubahan iklim lingkungan di luar menjadi iklim lingkungan di dalam. Ini artinya bahwa bangunan ikut membentuk sistem keseimbangan ekosistem.

\section{b. Iklim dan Budaya}

Budaya manusia sangat bergantung pada kemampuan manusia untuk saling berkomunikasi untuk setiap aktifitasnya. Iklim mempengaruhi pola aktifitas yang dilakukan baik secara langsung maupun tidak langsung. Oleh karena itu iklim mempunyai hubungan langsung dengan perkembanganbudaya. Pengaruh ini dapat dilihat bahwa iklim mampu memberikan kontak diantara manusia dan lingkungan sosial dan budaya.

\section{c. Iklim dan Bangunan}

Berdirinya bangunan di seluruh dunia terus bertambah secara bertahap. Manusiaberadaptasi dengan alam melalui bangunan dengan cara:

1. Mencari lokasi yang benar dan sesuai bagi huniannya.

2. Mencari orientasi yang benar

3. Membuat bangunan yang benar

4. Membuat penghuninya nyaman Sejak dahulu hingga sekarang manusia terus belajar mengatur interaksi bangunannya dengan kondisi iklim sekelilingnya yang sesuai untuk kehidupannya.

\section{d. Iklim dan Kenyamanan}

Iklim lingkungan diubah oleh bangunan menjadi lingkungan dalam yang mempengaruhi kenyamanan manusia sebagai pemakai bangunan. Iklim didalam ruangan yang baik dan tepat dapat membuat manusia beraktifitas dengan baik sesuai dengan kehendaknya. Oleh karena itu ada 2 persyaratan utama dari iklim dalam ruangan, yaitu Tidak menyebabkan tekanan (stress) yang mungkin dapat merusak sistem ekologi manusia dan Memberikan rasa aman pada manusia dan lingkungan yang berhubungan dengan aktifitasnya.

\section{Psikologi Manusia}

Pembahasan tentang arsitektur perilaku tidak terlepas dari psikologi. Psikologi adalah ilmu pengetahuan yang mempelajari tingkah laku manusia dalam hubungannya dengan lingkungan disekitarnya (Sarwono, 1992. Buku Psikologi Lingkungan). 


\section{Arsitektur Perilaku dan Lingkungan}

Manusia dikenal sebagai makhluk sosial yang tidak pernah lepas dari lingkungan yang membentuk diri mereka. Diantara sosial dan arsitektur dimana bangunan yang didesain manusia, secara sadar atau tidak sadar, mempengaruhi pola perilaku manusia yang hidup didalam arsitektur dan lingkungan tersebut. Sebuah arsitektur dibangun untuk memenuhi kebutuhan manusia dan sebaliknya, dari arsitektur itulah muncul kebutuhan manusia yang baru kembali (Tandal dan Egam, 2011).

\section{Perilaku Manusia Membentuk Arsitektur}

Manusia membangun bangunan, yang kemudian terjadinya pembentukan perilaku manusia itu sendiri. Setelah perilaku manusia terbentuk karena arsitektur yang telah dibuat, manusia kembali membentuk arsitektur yang telah dibangun sebelumnya atas dasar perilaku yang telah terbentuk, dan seterusnya. Setiap arsitektur yang dibuat atas dasar kebutuhan manusia menghasilkan efek perilaku yang berbedabeda terhadap arsitektur itu sendiri. Mengenai pembangunan kembali arsitektur yang diadaptasi dari kebutuhan dan perilaku manusia yang berdampak terhadap psikologi seseorang.

\section{Arsitektur Membentuk Perilaku Manusia}

Manusia membangun bangunan demi pemenuhan kebutuhan setiap penggunanya, yang kemudian bangunan itu membentuk perilaku pengguna yang hidup di dalam bangunan tersebut dan mulai membatasi manusia untuk bergerak, berperilaku, dan cara manusia dalam menjalani kehidupan sosialnya. Hal ini menyangkut kestabilan antara arsitektur dan sosial dimana keduanya hidup berdampingan dalam keselarasan lingkungan. Untuk membentuk perilaku manusia dapat dipengaruhi oleh beberapa perancangan fisik ruang, seperti ukuran dengan bentuk ruang, perabot dan penataannya, warna, suara, temperatur, dan pencahayaan.

\section{Variabel Fisik yang Mempengaruhi Perilaku Manusia}

Variabel fisik yang mempengaruhi perilaku manusia (Setiawan, 1995), antara lain:

a. Ruang. Hal terpenting dari pengaruh ruang terhadap perilaku manusia adalah fungsi dan pemakaian ruang tersebut. Perancangan fisik ruang memiliki variable yang berpengaruh terhadap perilaku pemakainya.

b. Ukuran dan bentuk. Ukuran dan bentuk ruang harus disesuaikan dengan fungsi yang akan diwadahi, ukuran yang terlalu besar atau kecil akan mempengaruhi psikologis pemakainya.

c. Perabot dan penataannya. Bentuk penataan perabot harus disesuaikan dengan sifat dari kegiatan yang ada di ruang tersebut. Penataan yang simetris memberi kesan kaku, dan resmi.Sedangkan penataan asimetris lebih berkesan dinamis dan kurang resmi.

d. Warna. Warna memiliki peranan penting dalam mewujudkan suasana ruang dan mendukuing terwujudnya perilaku-perilaku tertentu. Pada ruang, pengaruh warna tidak hanya menimbulkan suasana panas atau dingin, tetapi warna juga dapat mempengaruhi kualitas ruang tersebut.

e. Suara, Temperatur dan Pencahayaan. Suara diukur dengan decibel, akan berpengaruh buruk bila terlalu keras. Demikian pula dengan temperatur dan pencahayaan yang dapatmempengaruhi psikologis seseorang.

\section{METODE}

Metode secara umum yang digunakan untuk Rumah Susun Sederhana adalah Arsitektur Bioklimatik menggunakan metode deskriptif kualitatif untuk menjelaskan permasalahan serta memaparkan kondisi eksisting serta diidentifikasi sesuai dengan teori dan standard yang pernah digunakan, kemudian setelah itu dilakukan sintesis dan analisis. Penerapan metode ke dalam bangunan yang pertama adalah bahan material yang digunakan harus tepat agar tujuan dari metode itu sendiri yaitu ramah lingkungan dan berkelanjutan dapat dilakukan dengan benar, yang kedua adalah desain bangunan yang sesuai agar metode yang digunakan bisa lebih maksimal dan yang terakhir adalah penggunaan penhijauan dan bukaan yang tepat untuk bangunan maupun lansekap agar lebih maksimalnya tujuan dari arsitektur bioklimatik itu sendiri yaitu untuk menciptakan suatu lingkungan dan bangunan yang dirancang untuk sepenuhnya menutupi kebutuhan energi tanpa menyebabkan kerusakan lingkungan. 


\section{DISKUSI DAN HASIL}

\section{Tinjauan Tapak}

Tapak berada di Jl. Madrasah 2, RW.6, Cilandak Timur, Pasar Minggu, Jakarta Selatan, kondisinya merupakan lahan kosong yang terdapat beberapa vegetasi eksisting, serta jalan berada pada sisi selatan, barat dan timur yang kemudian berjarak 50-100meter berhubungan langsung dengan jalan primer dan sekunder. Peruntukan di sekitar tapak adalah perumahan dan fasilitas umum dan sosial yang dapat menunjang kebutuhan pelayanan umum dan sosial penghuni rusun. Adapun deskripsi tapak serta regulasi secara rinci dapat dapat dilihat sebagai berikut:
- Zona
$=$ Perumahan Vertikal/Sub Zona Rumah Susun
- Luas Tapak
$= \pm 27.000 \mathrm{~m}^{2}$
- GSB
$=4$ meter $(1,5 \times$ lebar jalan $)$
- KDB
$=40=10,800 \mathrm{~m}^{2}$
- KLB
$=3=81,000 \mathrm{~m}^{2}$
- $\mathrm{KB}$
$=16=-$
- $\mathrm{KDH}$
$=35=9,450 \mathrm{~m}^{2}$
- $\mathrm{KTB}$
$=50=14,850 \mathrm{~m}^{2}$

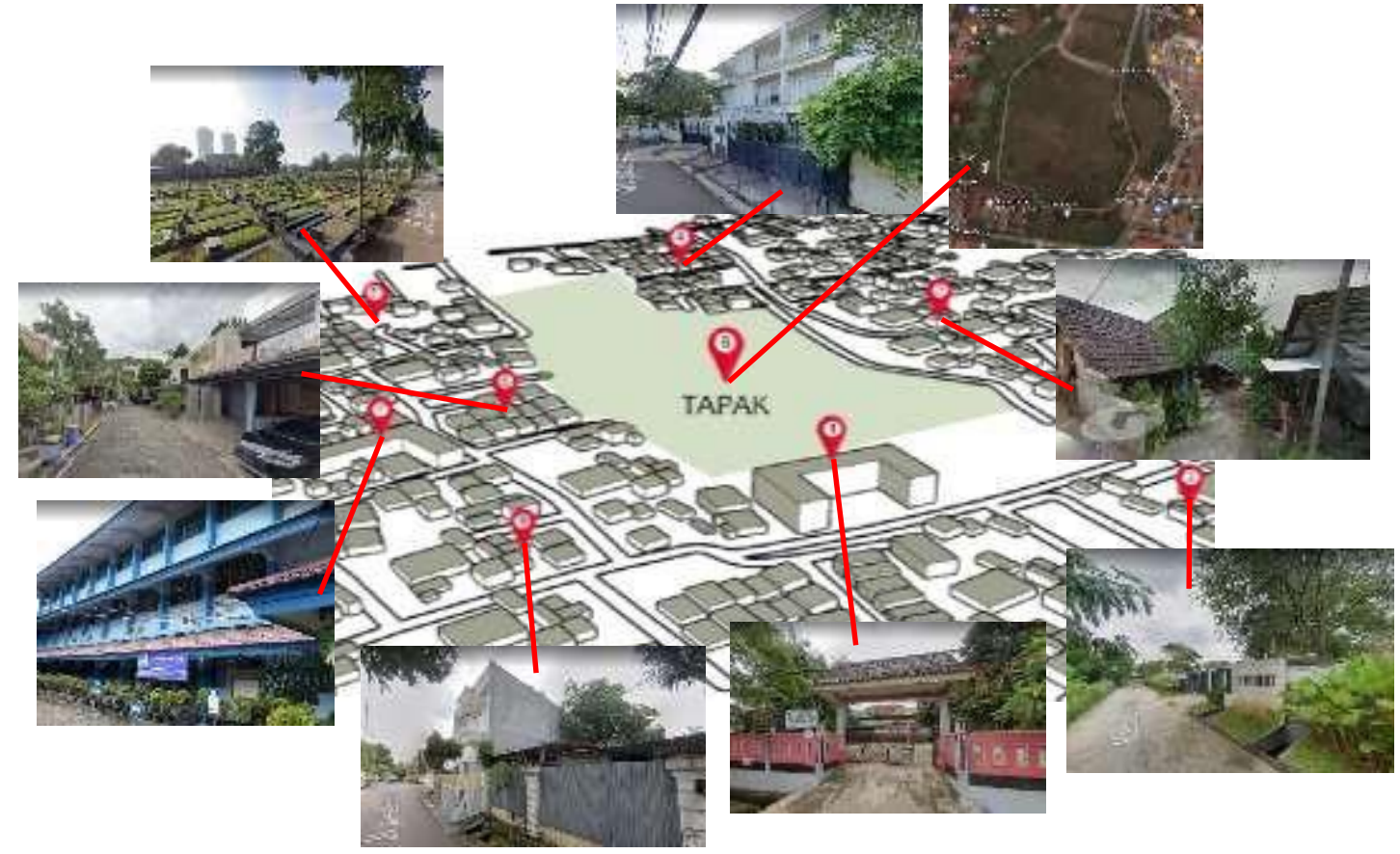

Gambar 2. Lingkungan Disekitar Tapak Sumber: Google Maps, 2021

\section{Konsep Desain Arsitektur Bioklimatik}

Arsitektur Bioklimatik merupakan salah satu ilmu dari Arsitektur Ekologis (Lingkungan) menurut Heinz Frick. Prinsip pada arsitektur lingkungan ini adalah cara yang digunakan, strategi yang ditempuh untuk merancang kawasan maupun bangunan, yang merespon iklim pada kawasan, skala iklim makro, maupun iklim mikro. Selain itu, arsitektur lingkungan juga dapat merespon cara untuk mencapai kenyamanan thermal yang diharapkan oleh pengguna pada bangunan. ArsitekturBioklimatik adalah pendekatan sinergis untuk desain arsitektural terhadap iklim, yang mengintegrasikan ilmu psikologi manusia, klimatologi dan integrasi ilmu fisika bangunan pada arsitektur regional (Krisdianto, Abadi, \& Ekomadyo, 2011, p.23). Disebutkan juga dalam (CRES, 2017) dalam (Petros, 2018, p. 3), Arsitektur Bioklomatik merujuk pada desain dari bangunan dan ruang (ruang dalam, ruang luar, dan lingkungan buatan) yang didasarkan iklim lokal yang bertujuan untuk menyediakan kenyamanan thermal dan kenyamanan visual, dengan menggunakan energi matahari dan sumber alami lainnya. 
Elemen dasar dari desain Arsitektur Bioklimatik adalah memanfaatkan sumber alami yaituair, matahari, udara, angin, tanaman, dan tanah untuk pemanasan, pendinginan dan pencahayaan pada bangunan. Arsitektur Bioklimatik memberikan banyak manfaat terkait lingkungan, sosial, dan ekonomi. Arsitektur Bioklimatik mengkombinasikan masing-masing dari keberlanjutan, kesadaran terhadap lingkungan, alam, dan pendekatan organik untuk perkembangan solusi berupa desain dari syaratsyarat yang ada serta dari karakteristik yang ada pada tapak, konteks lingkungan, dan iklim mikro lokal serta topografi (Almusaed, 2011, p. 219).

Kriteria perancangan dengan konsep Arsitektur Bioklimatik diperlukan adanya Batasan teknis dari perancangan bioklimatik dalam pengendalian iklim mikro bangunan agar tetap focus untukmencapai kesesuaian desain bangunan yang mampu beradaptasi dengan iklim setempat. Penerapan Arsitektur Bioklimatik pada rusunami ini antara lain adalah:

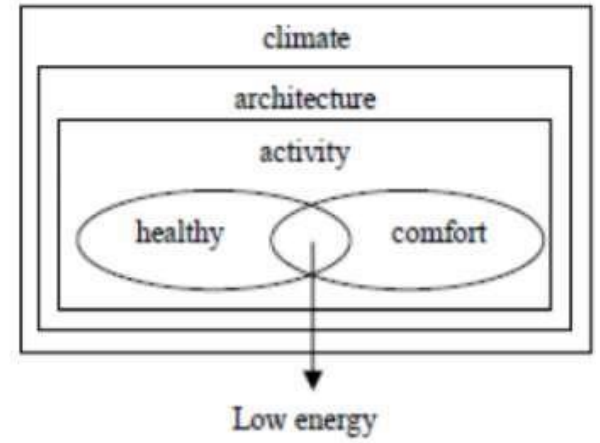

Gambar 3. Arsitektur Bioklimatik

Sumber: Jurnal Arsitektur Komposisi, 2020

\section{A. Orientasi}

Orientasi yang dipilih adalah orientasi yang menyesuaikan dengan bentuk dan akses ke tapak, meski tetap terdapat adany beberapa kelebihan dan kekurangannya. Orientasi menyesuaikan dengan aksesibilitas jalan adalah solusi lebih tepat karena agar bisa lebih efektif secara penggunaan lansekap lahan dan juga efektif secara aksesibilitas kendaraan umum maupun pribadi sehingga dapat mengoptimalkan lahan tapak untuk penghijauan dan jalanan disekitar tapak dari arah selatan dan barat.

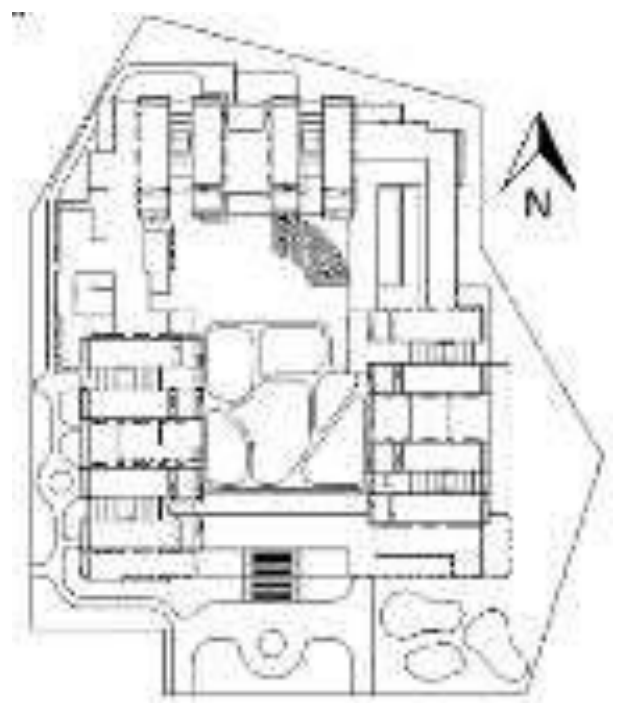

Gambar 4. Orientasi

Sumber: Penulis, 2021 


\section{B. Aksesibilitas}

Analisis aksesibilitas digunakan sebagai pemecah solusi dalam pencapaian menuju tapak. Berdasarkan eksisting kondisi tapak, pencapaian menuju tapak dapat diakses dengan menggunakan transportasi umum maupun kendaraan pribadi, karena memiliki akses yang dapat dijangkau kendaraan dan lebar jalan yang cukup untuk kendaraan bermobil dan bermotor. Terdapat adanya 7 titik transportasi umum seperti bus dan busway yang dapat dijangkau oleh penghuni rusun dengan jarak yang cukup dekat. Untuk menghindari adanya kemacetan yang berlebih, maka diberikan 2 pintumasuk dan pintu keluar untuk kendaraan. Yang pertama melalui Jl. Keuangan Daerah dengan lebar jalan 6 meter dan yang kedua melalui JI. Benda Atas dengan lebar jalan 4.5meter. Pintu masuk tersebut berada pada sisi selatan dan barat karena menurut analisis jalanan tersebut tidak macet danmemiliki lebar jalan yang paling besar dibandingkan sisi lainnya.
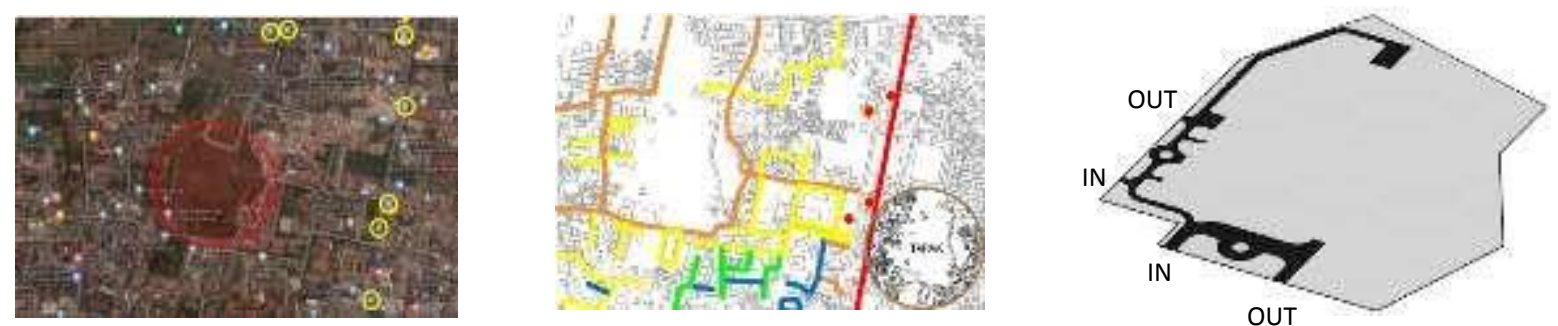

Gambar 5. Akses, Pencapaian, Sirkulasi Sumber: Penulis, 2021

\section{Bentuk Massa}

Berdasarkan besarnya kebutuhan ruang agar efektif dalam penggunaan lahan, maka massa bangunan terpecah menjadi tiga yaitu massa $A$, massa $B$, dan massa $C$. Bentuk massa yang memanjang atau linear memiliki keuntungan untuk peletakan posisi bukaan sepanjang sisi bangunan sehingga kebutuhan akan pencahayaan serta pengudaraan alami mencukupi.

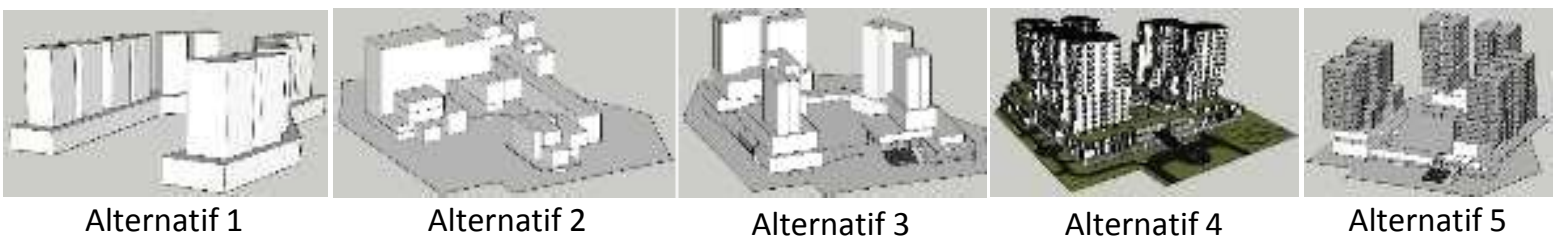

Gambar 6. Alternatif Bentuk Massa Bangunan

Sumber: Penulis, 2021

Alternatif desain yang dipilih pada analisa di atas adalah alternatif keempat karena memiliki keunggulan dalam hal pemenuhan kebutuhan ruang pada rusun dan juga memenuhi proporsi bentuk pada tapak. Tipe hunian rusun akan dibedakan menjadi beberapa tipe dengan tujuan untuk menyesuaikan kebutuhan tiap jumlah anggota penghuni/keluarga.

\section{Konsep Desain}

Konsep yang digunakan untuk seluruh desainnya adalah organik untuk meniru bentuk vegetasi yang tidak saling simetris. Penerapan desain bangunan bersifat alami dimana alam menjadi pokokdan inspirasi dari bentuk, desain, dan material yang digunakan. Konsep organik ini merupakan sebuah desain arsitektur yang terus berlanjut (sustainable), dimana tidak pernah berhenti dan selalu dalam keadaan dinamis yang selalu berkembang mengikuti zaman tanpa menghilangkan unsur keasliannya. 


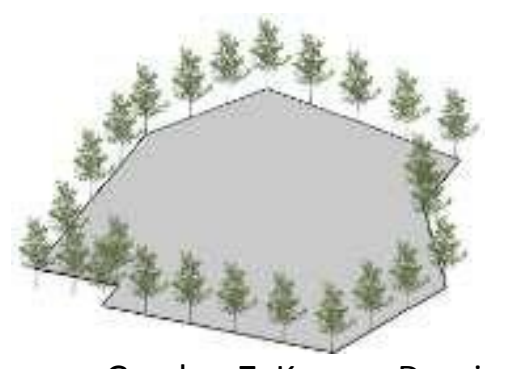

Gambar 7. Konsep Desain

Sumber: Penulis, 2021

\section{E. Solid dan Void Untuk Pencahayaan dan Pengudaraan Alami}

Pembahasan mengenai bukaan terbagi menjadi 2 pembahasan, yaitu analisis bukaan untuk pencahayaan dan untuk pengudaraan. Permasalahan utama yang terlihat adalah bentuk bangunan yang terjadi adanya blocking/menutupi pencahayaan dan pengudaraan untuk masuk. Kemudian permasalahan kedua mengenai solid dan void bangunan serta upaya untuk mengoptimalkan fungsi void bangunan untuk mengalirkan udara dan pencahayaan masuk kedalamnya. Berikut merupakan solusi dari kedua permasalahan yang disebutkan, dengan proses bentuk desain yang bertujuan untuk optimalkan penghawaan alami serta pencahayaan yang merata:
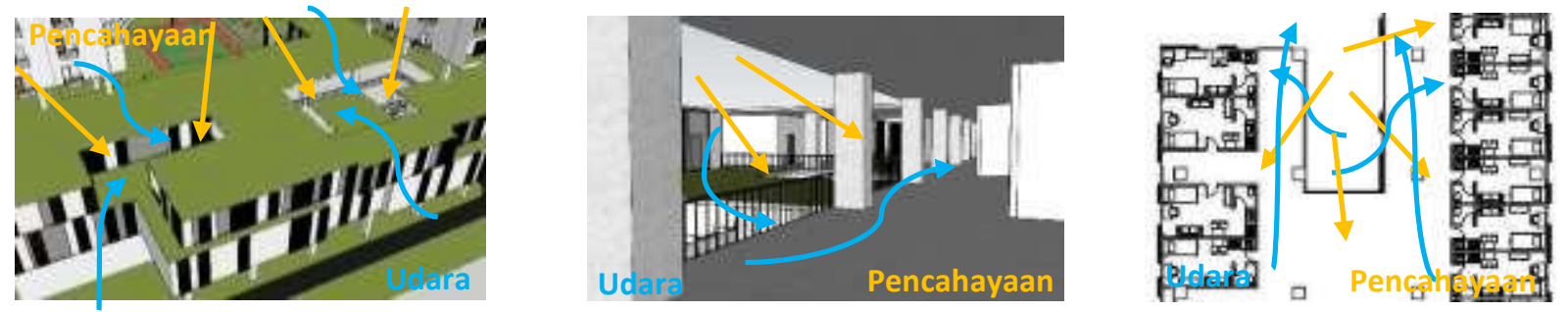

Gambar 8. Solid Dan Void Untuk Pencahayaan Dan Pengudaraan Alami

Sumber: Penulis, 2021

Bentuk dari bangunan rusun ini terbilang sangat besar yang kemungkinan akan terjadi adanya titik-titik minim cahaya dan udara di bagian tengah ruangan. Maka dari itu diberikan adanya solid danvoid agar terjadi adanya pengudaraan dan pencahayaan alami masuk kedalam ruangan. Di setiap lantai podium dan hunian rusun ini diberi void agar udara dapat lewat dengan bebas dan tidak terhalang. Kelebihan pada proyek ini adalah menggunakan sistem single corridor dan terdapat adanya void di tengahnya yang bertujuan agar bisa terjadi adanya penghawaan silang pada setiap bangunan nya dan tidak terjadi adanya blocking.

\section{F. Integrasi}

Integrasi pada bangunan ini adalah untuk menghubungkan dan memanfaatkan luar dan dalam ruang area solid dan void. Manfaat dari integrasi bangunan ini selain untuk efektivitas pengunaan lahan, ruang, dan thermal tetapi berdampak baik untuk kesehatan psikologi manusia yang tinggal didalamnya karena setiap penghuninya dapat menikmati ruang luar dan dalam secara bebas dengan view vegetasi yang banyak di area dalam maupun luar bangunan.
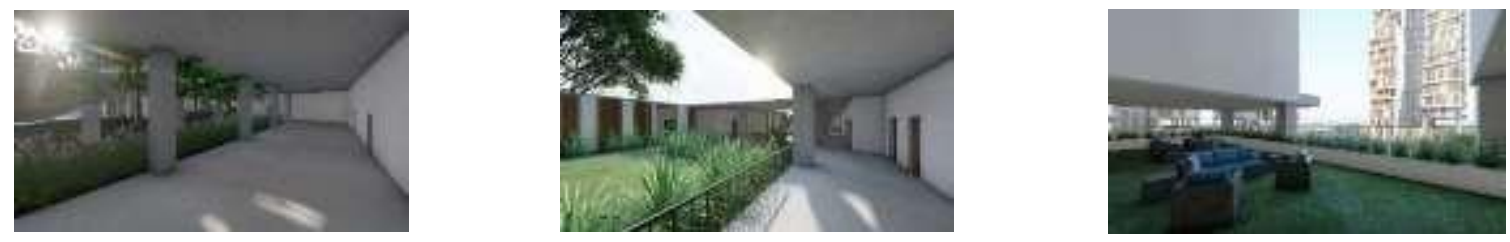

Gambar 9. Integrasi Luar Dan Dalam Ruang Sumber: Penulis, 2021 


\section{G. Vegetasi dan Lansekap}

Peletakan vegetasi pada area tapak dan bangunan berperan sebagai penyerap radiasi matahari dan bising sehingga mampu menurunkan suhu dan kebisingan ruangan dan lingkungan. Aplikasi vegetasi terbagi menjadi 2 metode, yang pertama perletakan vegetasi pada lansekap sebagai pengisi taman di sekitar tapak, dan yang kedua perletakan vegetasi pada bangunan yang bertujuan untuk membantu mengurangi suhu dan kebisingan dalam bangunan. Berikut merupakan aplikasi vegetasi yang akan diletakkan kedalam tapak dan juga pada bangunan:

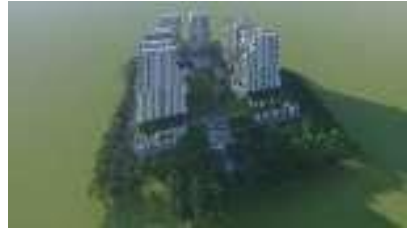

Gambar 10. Vegetasi Dan Lansekap

Sumber: Penulis, 2021

H. Material Bangunan
Material bangunan yang dig

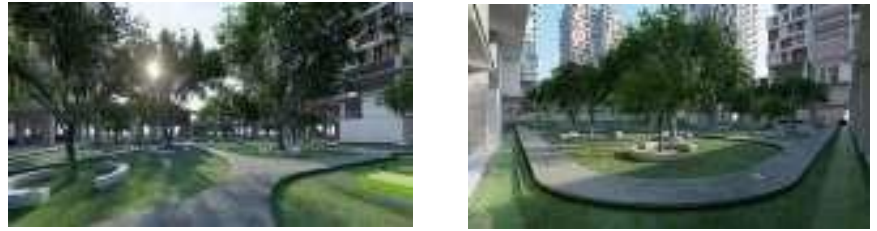
dari itu bangunan rusun ini menggunakan material yang sustainable dan ramah lingkungan. Bahan material yang pertama adalah hempcrete, hempcrete ini adalah bahan biokomposit, kelebihan pada bahan ini adalah kuat, ringan, hemat energi, sebagai isolator dan pengatur kelembaban, tahan akan api, tahan terhadap air dan serangga, hasilnya adalah bahan isolasi ringan yang ideal untuk sebagian besar iklim karena menggabungkan isolasi dan massa termal. Yang kedua adalah kayu, kayu tidak hanya sebagai bahan bangunan yang ramah lingkungan, namun kayu juga mudah menyesuaikan diri terhadap lingkungannya. Kayu responsif terhadap suhu, kelembapan udara, dan suara. Sifat kayu yang higroskopis membuat kayu mampu menyerap kelembapan dan melepaskan kadar air ke udara. Material kayu baik untuk menjaga keseimbangan suhu dan kenyamanan pada bangunan dan juga memiliki sifat akustik yang dapat menyerap suara. Ketiga adalah kaca, walaupun kaca dikenal sebagai material penghantar pantas, namun kaca juga bermanfaat untuk penghematan pemakaian lampu karena cahaya luar masuk kedalam ruangan, maka dari itu material kaca diberikan dibeberapa ruangan seperti mini market, paud, dll. Bahan material yang terakhir digunakan adalah panel prefab, panel prefab memiliki kemampuan dan ketahanan terhadap guncangan gempa, tidak hanya mampu menahan guncangan gempa bumi panel pre-fab juga memiliki material yang lebih tahan panas seperti api, manfaat lainnya panel prefab juga lebih mudah dan cepat untuk dipasang dan memiliki harga yang lebih murah dan ringan.

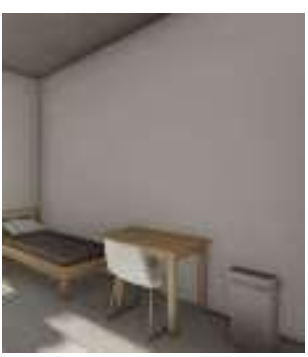

\section{KESIMPULAN DAN SARAN}

\section{Kesimpulan}

Rumah susun yang terdapat pada Pasal 3 Ayat (1) Undang-Undang No. 20 Tahun 2011 diantaranya meningkatkan efisiensi dan efektivitas pemanfaatan ruang dan tanah, serta menyediakan ruang terbuka hijau di kawasan perkotaan dalam menciptakan kawasan permukiman yang lengkap serta serasi dan seimbang dengan memperhatikan prinsip pembangunan berkelanjutan dan berwawasan, memenuhi kebutuhan sosial dan ekonomi yang menunjang kehidupan penghuni dan masyarakat dengan tetap mengutamakan tujuan pemenuhan kebutuhan perumahan dan permukiman yang layak, terutama bagi MBR (masyarakat berpenghasilan rendah). 
Arsitektur Bioklimatik merupakan desain arsitektur yang mampu beradaptasi dengan kondisi lingkungan di sekitarnya, dan seminimal mungkin untuk tidak merusak alam. Bentuk massa yang menanggapi kondisi iklim setempat dengan menggunakan sistem solid, void, dan integrasi, mampu menjadi solusi terhadap permasalahan pencahayaan dan penghawaan. Kriteria bukaan tersebut mampu mendesain bangunan secara pasif dengan menerapkan konsep penghawaan silang. Kemudian material bangunan menjelaskan material yang sesuai dengan iklim disekitarnya yang bertujuan agar mampu mengurangi tingkat panas dan kelembaban dalam bangunan, maka bangunanrusun sederhana milik dengan tema arsitektur bioklimatik dinilai cukup efisien meski tidak $100 \%$, meskipun demikian kriteria arsitektur bioklimatik seperti elemen vegetasi, desain yang baik dan pemilihan material yang tepat mampu mengurangi radiasi matahari sangat membantu dalam menurunkan suhu dalam ruangan.

\section{Saran}

Berdasarkan hasil penelitian dan kesimpulan yang telah dijelaskan sebelumnya, penulis memberikan beberapa saran, diantaranya sebagai berikut:

1. Desain Arsitektur Bioklimatik dalam penelitian ini sangat efektif dan bermanfaat pada penghuni dan lingkungan sekitarnya, oleh karena itu penulis menyarankan untuk mempertimbangkan kembali konsep dari Arsitektur Bioklimatik ini untuk digunakan terhadap pembangunan di Indonesia di masa depan agar lebih ramah lingkungan.

2. Meskipun penulis menginginkan kesempurnaan dalam penyusunan jurnal ini akan tetapipada kenyataannya masih banyak kekurangan yang perlu penulis perbaiki. Hal ini dikarenakan masih minimnya pengetahuan penulis. Oleh karena itu penulis menyarankan perlu adanya metode penelitian yang lebih lanjut agar peneliti selanjutnya dapat mengupas secara lebih dalam mengenai penerapan Arsitektur Bioklimatik terhadap bangunan, sehingga data yang diperoleh lebih berkualitas.

\section{REFERENSI}

Aronin, J. E. (1953), Climate and Architecture, Reinhold Publishing Company, NewYork.

Endang S., E. (2006). Faktor-Faktor Yang Mempengaruhi Terciptanya Kawasan Kumuh Di Kawasan Pusat Kota. Program Studi Magister Teknik Pembangunan Wilayah dan Kota: Universitas Diponegoro

Halim, D. (2005) Psikologi Arsitektur: Pengantar Kajian Lintas Disiplin, Jakarta:PTGrasindo Irfandi. (2017). Pengaruh Iklim Terhadap Arsitektur. Jurusan Arsitektur: Universitas Syiah Kuala Nurhijrah, R. W., Abdul Mufti Radja. (2019). Manfaat Ruang Terbuka dan Hubungan dengan Kegiatan Interaksi Sosial. Jurusan Arsitektur: Universitas hasanuddin, Indonesia

Sheila, L. (2014). Tinjauan Teori Pendekatan Arsitektur. Jurusan Arsitektur: Universitas Sumatera Utara Watson, D. (1983), Climatic Design: Energy-Efficient Building Principles and Practices,Mc Graw Hill, Inc. United States of America.

Widera, Barbara (2015, April 25). Bioclimatic Architecture. https://www.researchgate.net/publication/276936877_Bioclimatic_architecture

Widiawaty, M. A. (2019, April 4). Faktor-Faktor Urbanisasi di Indonesia. https://doi.org/10.31227/osf.io/vzpsw

Nathalia, (2017, December 1). Rumah flat : Pengertian, Cara Pembangunan, Kelebihan dan Kekurangannya. https://rumahlia.com/tips-trik/info-dasar/rumah-flat

Ardiyanto, Wahyu (2020, June 16). 7 Material Bahan Bangunan Yang Ramah Lingkungan. https://www.rumah.com/berita-properti/2020/6/189154/7-material-bahan-bangunan-yangramah-lingkungan

Kompas (2020, July 11). Jumlah Penduduk Dunia 2020. https://www.kompas.com/skola/read/2020/07/11/140300869/jumlah-penduduk-dunia- 2020 